\title{
From Business Modelling to the Leadership and Innovation in Business: Bibliometric Analysis (Banking as a Case)
}

http://doi.org/10.21272/bel.4(1).113-125.2020

Tetiana Goncharenko, ORCID: https://orcid.org/0000-0001-6298-4517

$\mathrm{PhD}$, Associate Professor, Sumy College of Economics and Trade, Sumy, Ukraine

\section{Abstract}

The analysis of approaches to defining the banking business model showed that digital financial technologies, e-commerce, information management are important factors that form the model of leadership and innovation in business. The development of risk management, risk assessment, profitability-risk-stability triangle balancing, which create relevant trends in the formation of business leadership models, has increasing importance for managers, clients and shareholders. The article identifies the dominant tendencies in the development of scientific thought (based on 6377 articles from 1991-2019 in journals indexed by Scopus and Web of Science) regarding the transformation of business models in banks and the future research directions with the help of bibliometric analysis (VOSviewer). The conducted analysis showed that in 2012-2017 the number of scientific articles about the transformation of banks' business models began to increase. It proves the relevance of business modelling for leadership and innovation in business. At the same time, the focus of research has shifted from general strategic management issues to risk management issues. In 2017, the number of articles studying the banking business model increased by $148 \%$ compared to 2012 . Therefore, these articles in the subject area observe such areas as business, management, economics, econometrics, finance, social and computer sciences. Among the scientists who studied the banks' business models, most are scientists from the US, UK and India. In 2018, there was a significant increase in the number of articles on banking strategic management published in high impact journals, such as the Journal of Banking and Finance, the International Journal of Bank Marketing and Economic Modeling. The use of the VOSviewer has identified 8 research clusters exploring the issue from different perspectives. The first (largest) cluster consists of studies that examine banks' business models through decision-making and information management technologies, risk assessment and minimization mechanisms, the relationship between banking sales dynamics and the information databases etc. The second-largest cluster brought together researchers examining banks' business models in terms of the financial crisis effects, regulatory changes, business efficiency and stability (z-score), etc. The third-largest cluster is the study of business models through the dynamics of transformations in the financial market, in lending behaviour and business cycles. These three largest clusters confirm that the key to leadership and innovation in banking is the balance between the profitability-risk-stability triangle and information technology.

Keywords: Bank, Banking, Business Model, Leadership and Innovations in Business.

JEL Classifications: E5, M2, O3.

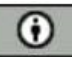

This work is licensed under a Creative Commons Attribution 4.0 International License

Cite as: Goncharenko, T. (2020). From Business Modelling to the Leadership and Innovation in Business: Bibliometric Analysis (Banking as a Case). Business Ethics and Leadership, 4(1), 113-125. http://doi.org/10.21272/bel.4(1).113-125.2020.

(C) The Author, 2020. This article is published with open access at Sumy State University.

\section{Introduction}

The ongoing tendency on extending the banking regulation, the appearance of fintech innovation lead to a reorientation of the business activities banks, disappearance one's business models and appearance others. The strategic management terminology in the banking industry started to be used more frequently in the last decade after the World financial crisis 2007-2009, both by academics and banking professionals. In this paper, we performed a literature review regarding the use and the connections of business model terminology in the banking industry. First, the study aims to summarize the level of knowledge of business model terminology in the banking industry. A second aim is to correlate published material regarding business model to answer the 
question regarding that terminology have strong connections with banking, information technology and regulation. Thus, at the first stage, the definition, principals and features of banking business model should be defined. Noted, that traditionally banking business model analysed with business strategy and market strategy (financial). However, the huge range of scientists in the papers (Osterwalder, 2004) analysed of banking business model as a synonym of banking strategic management which influences on the risk taken, profitability and soundness of banks. We used selective criteria like articles published in Clarivates, ScienceDirect, Scopus or Web of Sciences. Finally, the article proposes that as a future study we ought to analyse the link between strategy and business models on a sample of financial institutions.

\section{Literature Review}

The widespread use of banking business mode terminology in academic literature is linked recently with the requirement of financial and bank regulator and development of technology companies.

The business models analysis was first introduced by Ayadi et al. (2011) in an initial attempt to identify the business models of 26 European banking institutions and to assess their performance between 2006 and 2009. The main finding indicated that the retail banking model has seemingly fared better through the crisis, compared to the other identified business models, namely investment and wholesale banks. The authors further recommended an annual monitoring exercise of bank business models to better understand their evolution within the macro and microeconomic contexts. The first pilot exercise, monitoring the business models of 147 banks, was released in December 2014 in (Ayadi \& De Groen, 2014), to test the relevance of this approach. A more comprehensive monitoring exercise was launched in January 2016 in (Ayadi et al., 2016), which extended the sample from 147 banks to 2,542 banks, covering more than 95\% of total assets of the European Union plus EFTA countries from 2005 to 2014 and accounting for 13,040 bank-year observations. The newest Monitor edition for Europe in (Ayadi et al.,2019) provides an updated identification of BBM for 3,287 banking groups and subsidiaries in the European Economic Area (EEA) and Switzerland, accounting for 25,402 bank-year observations and using Ayadi (2019) definition, methodology and financial stability framework.

Early the scientists in the paper (Osterwalder, 2004) associate's strategy, business models and process model (indeed on different business layers), considering that the words are addressing a similar problem. At the same time, in the papers (Magretta, 2002) asserts that strategy is not a business model, making a clear distinction between the two terms. Recently, opinions of Wirtz et al. (2016) are that the term strategic management needs additional researches, especially regarding the link between business models concept and other consecrated concepts in business management, including strategy.

Although there are many comprehensive studies about the business model terminology and concepts, Zott, Amit and Massa (2011) argue that there are no definite conclusions of scholars about what business model is, and the literature provides definitions that strongly relate with the theme of interest that scholars are covering. DaSilva and Trkman (2014: 379) have been pointing out that the term "has been misinterpreted and misused over the years and has consequently been inadequately understood and applied by both practitioners and scholars".

Banking history suggests, that banks suffered enormous losses due to lack of proper strategic management. Beltratti and Stulz (2009) observed poor and flexible management and very low-risk appetite which caused banks serious liquidity and financial issues.

The results of the analysis showed that range of scientists (Sanjeepan, N., 2017) have formed strategic planning based on an ample interpretation of banking sector that, along with the instruments and techniques from which it stems, there is an essential condition to operate in competitive markets. The concept of planning is examined in its stages, its importance and the benefits for the banking sector in implementing scheduling. The strategic plan model proposed here for the banking sector is examined in detail through the steps towards implementing a plan leading to business improvement.

The authors in the paper (Alani et al., 2018) analysing the linking between strategic orientation and product innovation identified that knowledge management was the core elements of strategic management.

Using direct evaluations, the scientists in the papers (Demidova et al., 2019; Sokolenko et al., 2017) analyze heterogeneity among the various business strategies that incorporate systemically important banks. They identify the true banking model in a portfolio context, that is, consisting of various combinations of bank assets 
and funding sources. Next, they estimate the way distinct strategies have affected bank profitability and risk before the crisis, as well as their impact on the mortgage crisis.

Famous expert of World bank (Demirgüç-Kunt, A., Huizinga, H., 2010) examines the implications of bank activity and short-term funding strategies for bank risk and return.

The scientists (Björk, 2015; Lautenschläger, 2017; Finnegan, 2016; Barnes, 2015; Ogden, 2017; Accenture, 2015) analysing the banking industry indicator during its going through digital changes. It is cheaper to keep loyal customers than to acquire new ones (Björk, 2015). Customer migrated to digital channels. Mobile channels are far more likely to delight and less likely to annoy than the branch or call centre experiences. It causes an increase in loyalty with higher customer retention, repeat purchases and referrals. Customers increasingly expect to follow up with bank staff through digital chat, video or other real-time options and banks actively develop them (Bain \& Company). Representatives of international financial institutions (Lautenschläger, 2017) considers that FinTech will change banks and could be three scenarios: banks might team up with FinTech, FinTech might break up the value chain of banking and FinTech could be swallowed up by big Tech companies and deeply transform the banking business. Digital challengers and FinTech giants present a threat for banks and will not go away soon, but at the same time, a wave of innovation in the financial sector offers several opportunities for banks, who able to move quickly (Finnegan, 2016). The banks will gain from many innovations. Square, for instance, is a system that makes it easier for small businesses to take card payments; it will boost banks' transaction volumes. The FinTech revolution will reshape finance and improve it (Financial services, 2015). New banks are operating only digital models and giving to their customers a full range of banking services in smartphone (Barnes, 2015). App in the smartphone can offer advice on wealth building, spending habits, money-saving tips (Ogden, 2017). Customers move at different speeds and make different decisions, every customer is a digital customer now - someone more and someone less, from the traditional customer to the digital-savy one (Accenture, 2015).

The findings proved, that despite huge range investigations of the bank, their risk, profitability, market strategies, business strategies and models from different points of views, the banking business model issues have not analysed yet considering different aspects of bank activities, digitalisation, fintech innovation etc. In this case, the aim of the paper was analysed due to the tendency in the scientific literature on banking business model to identify future research directions.

\section{Methodology}

The main hypothesis of investigation is cheeking the increasing tendency on analysing of banking business model issues by the scientists. For this purpose, the investigation was done in the following scheme:

1. Identifying the quantity tendency of the papers which focused on the analyses of banking business model issues.

2. Allocating the main subject areas under analyses of banking business model issues.

3. Identifying the most citation papers and journals which contained the papers on banking business model.

4. Clustering the papers on the main directions for investigations with the purpose to identify the further options for analyses.

For the analysis, the following keywords were chosen: bank, banking, banking sector, banking business model. This study reviewed 6377 papers from Scopus and Web of Science. The time for analysis were 1991-2019. The analysis was done by using the software of VOSviewe, WoS analyse and Scopus analyses. Thus, VOSviewer allows to allocate and visualize the network of definitions which used and co-citation during the investigation of banking strategic management. Scopus and WoS tools allowed to analyse the publication towards different parameters: affiliation, journal, citation, number of the papers, funding, the subject area and citations. Thus, in the network visualization of VOSviewer allow to allocate and visualize the scientific direction which has strong relationships. The closer keywords are located to each other, the stronger their relations.

\section{Results}

The findings of analysing proved that the numbers of paper which focused on banking business model in the database Scopus has been steadily increasing over the whole analysed period, with an average growth rate of $26 \%$. The similar situation is observed with the numbers of paper which focused on banking business model, which published in the journals indexed by the WoS database, thus this database shows a significant growth rate of 
publications from 2013 to 2017 . This may be justified by the widespread problems associated with the active introduction of digital technologies in the banking business, and a corresponding change in the paradigm and types of business models of banks in the relation to fintech innovations, the emergence of cryptocurrencies, changes in the regulatory environment, and so on. In 2017 the number of papers which analysed the banking business model was increased by $148 \%$ compared with the 2012 year (Figure 1).

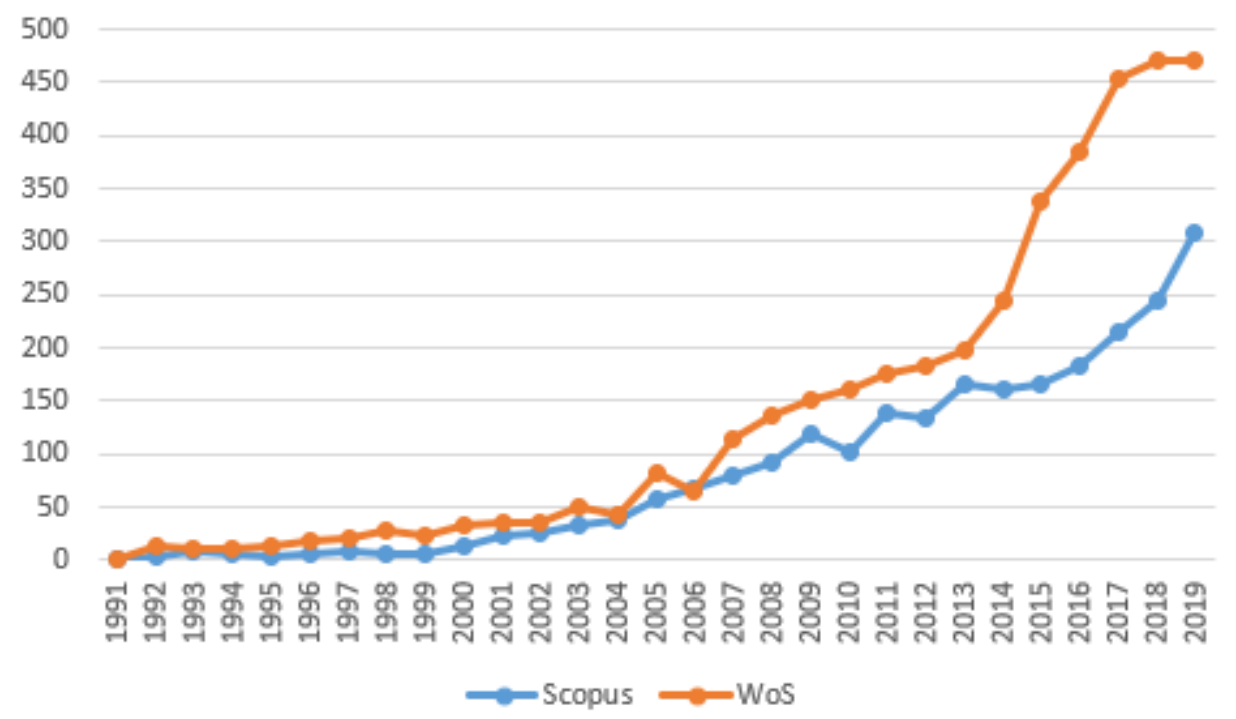

Figure 1. The number of documents in Scopus and WoS which contain the banking business model issues Source: Compiled by the author using data from Scopus and WoS

The findings proved that the banking business model was analysed according to data of Scopus in the framework of the subject area as follows: Business and Management - 23.86\%; Economics, Econometrics and Finance - 22.49\%; Computer science - 16.98; Social Sciences - 10.18\%; and others (Engineering, Decision Sciences, Mathematics etc.) $-26.49 \%$.
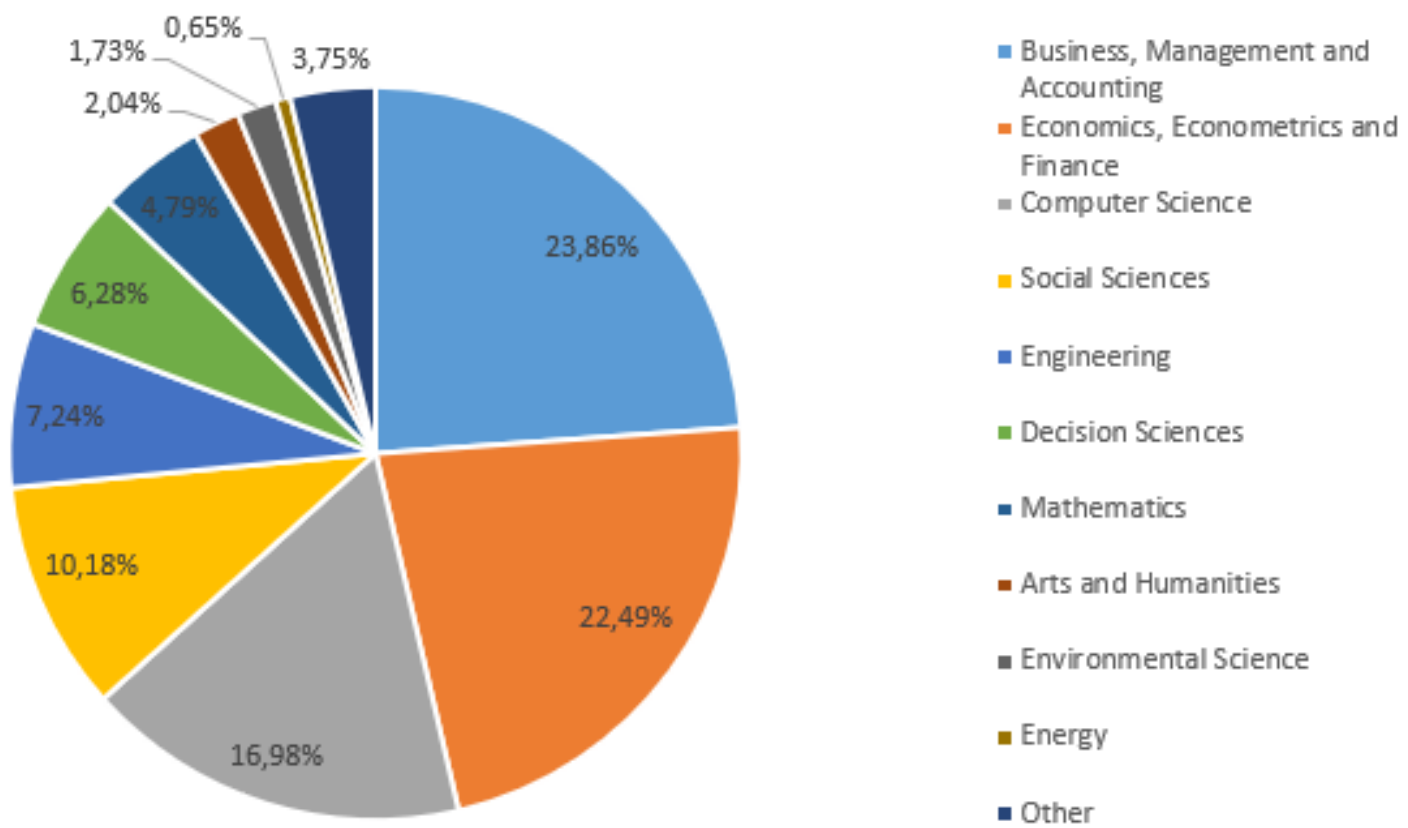

Figure 2. The subject area in Scopus for analysing the banking business model issues

Source: Compiled by the author using data from Scopus

According to data of $\mathrm{WoS}$ in the framework of the subject area the banking business model was analysed as follows: Economics - 18.87\%; Management - 10.55\%; Business Finance $-10.35 \%$; Business - 9.68\%; and others (Social science, Development study etc.) $-50.55 \%$. 


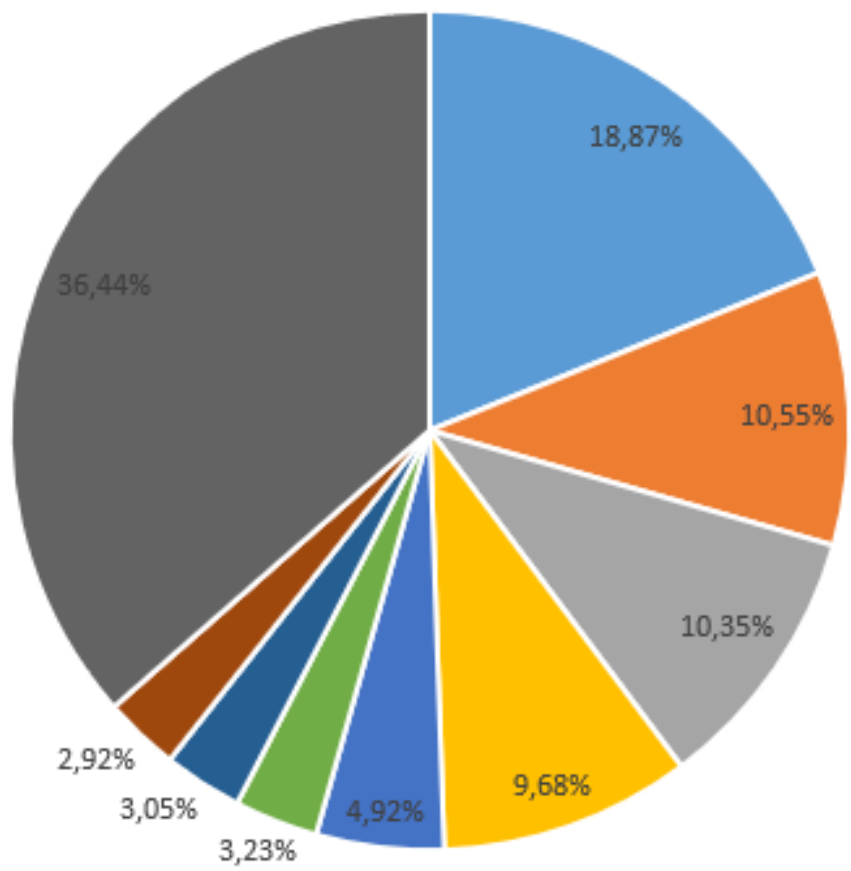

\author{
- Economics \\ - Management \\ n Business Finance \\ - Business \\ - Computer Science Information \\ Systems \\ - Operations Research Management \\ Science \\ - Computer Science Theory Methods \\ - Engineering Electrical Electronic \\ - Other
}

Figure 3. The subject area in WoS for analysing the banking business model issues

Source: Compiled by the author using data from WoS

The analysis by country showed that mostly the scientist with the USA, United Kingdom, India and China affiliations investigated the banking business model issues. The top 20 countries' affiliation of the scientists which investigated the banking business model issues according to the WoS database is showed in Figure 4. Figure 4 also demonstrates the number of publications from these countries in the Scopus database.

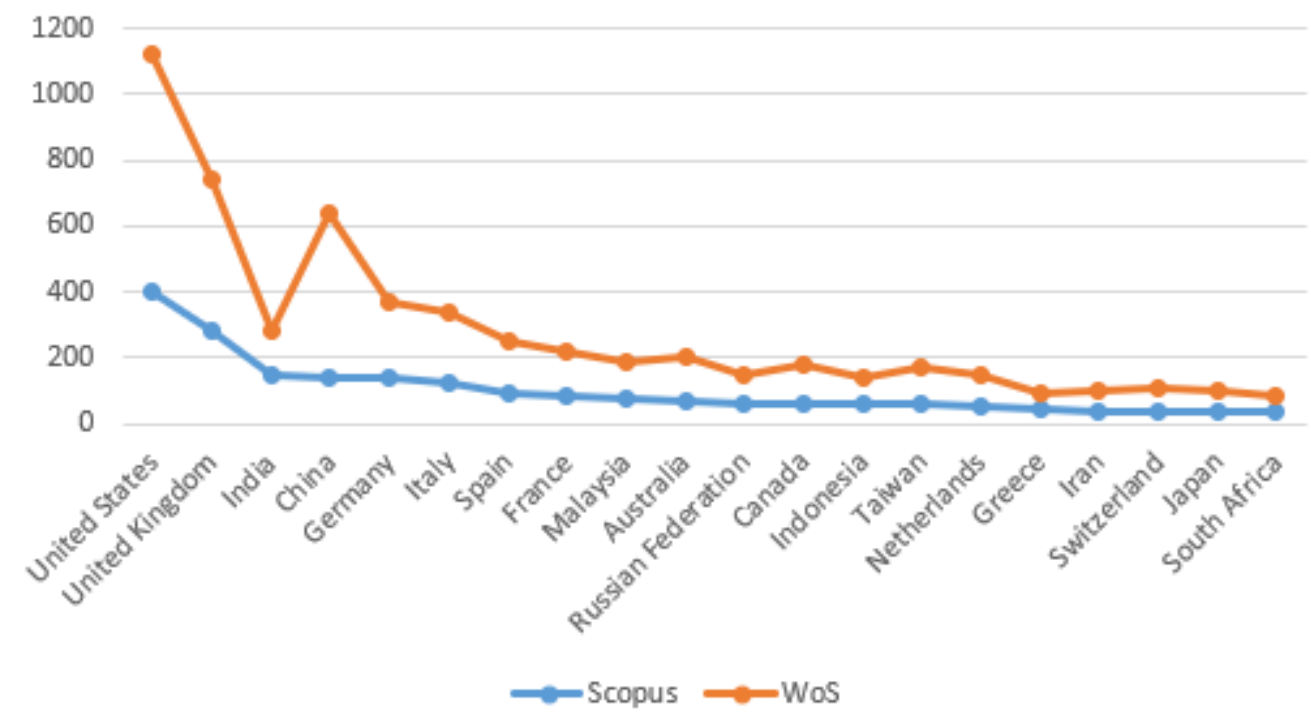

Figure 4. Top 20 countries' affiliations of the scientists which investigated the banking business model issues

Source: Compiled by the author using data from WoS and Scopus

Besides, considering the findings from Scopus in 2018 the high ranked Journal of Banking And Finance, Banks and Bank Systems, International Journal of Bank Marketing began to publish more papers on banking business model issues (Table 1). 
Table 1. The top 5 journals, indexed by Scopus, which published the papers on banking business model

\begin{tabular}{|l|c|c|c|c|c|}
\hline \multicolumn{1}{|c|}{ Title of the Journal } & Covered by Scopus & $\begin{array}{c}\text { CiteScore } \\
\mathbf{2 0 1 8}\end{array}$ & $\begin{array}{c}\text { SJR } \\
\mathbf{2 0 1 8}\end{array}$ & $\begin{array}{c}\text { SNIP } \\
\mathbf{2 0 1 8}\end{array}$ & $\begin{array}{c}\text { Numbers of } \\
\text { the papers }\end{array}$ \\
\hline Journal of Banking And Finance & & 3.08 & 1.599 & 1.857 & 23 \\
\hline Banks and Bank Systems & 1977 to 2019 & 0.42 & 0.210 & 0.514 & 22 \\
\hline International Journal of Bank Marketing & 2006 to 2019 & 3.31 & 0.76 & 1.468 & 21 \\
\hline Journal of Financial Services Research & 1987 to 2019 & 1.86 & 0.965 & 1.307 & 18 \\
\hline Annals of Operations Research & 1984 to 2019 & 2.58 & 1.032 & 1.334 & 15 \\
\hline
\end{tabular}

Source: Compiled by the author using data from Scopus

Table 2. The top 5 journals, indexed by WoS, which published the papers on banking business model

\begin{tabular}{|c|c|c|c|c|c|}
\hline Title of the Journal & $\begin{array}{c}\text { Impact } \\
\text { Factor } 2018\end{array}$ & $\begin{array}{c}\text { JCR }{ }^{\circledR} \\
\text { Category } \\
\end{array}$ & $\begin{array}{l}\text { Rank in } \\
\text { Category }\end{array}$ & $\begin{array}{l}\text { Quartile in } \\
\text { Category }\end{array}$ & $\begin{array}{l}\text { Numbers of } \\
\text { the papers }\end{array}$ \\
\hline \multirow{2}{*}{ Journal Of Banking And Finance } & \multirow{2}{*}{2.05} & Business, Finance & 27 of 103 & $\mathrm{Q} 2$ & \multirow{2}{*}{77} \\
\hline & & Economics & 79 of 363 & Q1 & \\
\hline Economic Modelling & 2.056 & Economics & 93 of 363 & $\mathrm{Q} 2$ & 49 \\
\hline $\begin{array}{l}\text { Journal of Economic Dynamics \& } \\
\text { Control }\end{array}$ & 1.502 & Economics & 148 of 363 & Q2 & 44 \\
\hline \multirow{2}{*}{ Journal of Money Credit and Banking } & \multirow{2}{*}{1.782} & Business, Finance & 40 of 103 & Q2 & \multirow{2}{*}{44} \\
\hline & & Economics & 119 of 363 & Q2 & \\
\hline Journal of Macroeconomics & 0.91 & Economics & 243 of 363 & Q3 & 34 \\
\hline
\end{tabular}

Source: Compiled by the author using data from WoS

According to Scopus database 9 from 10 the most cited papers were published by the high ranked journals. The most cited papers were published by the scientists Rust, R.T., Zahorik, A.J. in 1993 in Journal of Retailing (Table 3). In 2013 famous scientists and expert of World bank Beck T., Demirgüç-Kunt A., Merrouche O. published the paper "Islamic vs. conventional banking: Business model, efficiency and stability" which cited 394 (Table 3) and examined the difference between Islamic banks and conventional banks. They found few significant differences in business orientation, also they found evidence, that Islamic banks are less costeffective, but have a higher intermediation ratio, higher asset quality, are better capitalized and less likely to disintermediate during crises.

Table 3. The most cited papers on banking business model 1991-2019 according to Scopus database

\begin{tabular}{|l|c|c|c|}
\hline \multicolumn{1}{|c|}{ Authors and Title } & Year & Source title & Cited \\
\hline $\begin{array}{l}\text { Rust, R.T., Zahorik, A.J. Customer satisfaction, customer retention, and } \\
\text { market share }\end{array}$ & 1993 & Journal of Retailing & 1025 \\
\hline $\begin{array}{l}\text { Stein, J.C. Information production and capital allocation: Decentralized } \\
\text { versus hierarchical firms }\end{array}$ & 2002 & Journal of Finance & 732 \\
\hline $\begin{array}{l}\text { Meuter, M.L., Bitner, M.J., Ostrom, A.L., Brown, S.W. Choosing among } \\
\text { alternative service delivery modes: An investigation of customer trial of } \\
\text { self-service technologies }\end{array}$ & 2005 & Journal of Marketing & 689 \\
\hline $\begin{array}{l}\text { Anderson, E.W., Fornell, C., Rust, R.T. Customer satisfaction, } \\
\text { productivity, and profitability: Differences between goods and services }\end{array}$ & 1997 & Marketing Science & 653 \\
\hline $\begin{array}{l}\text { Berger, A.N., Udell, G.F. Small business credit availability and } \\
\text { relationship lending: The importance of bank organisational structure }\end{array}$ & 2002 & Economic Journal & 624 \\
\hline $\begin{array}{l}\text { Sampson, S.E., Froehle, C.M. Foundations and implications of a } \\
\text { proposed Unified Services Theory }\end{array}$ & 2006 & $\begin{array}{c}\text { Production and } \\
\text { Operations Management }\end{array}$ & 396 \\
\hline $\begin{array}{l}\text { Beck, T., Demirgüç-Kunt, A., Merrouche, O. Islamic vs. conventional } \\
\text { banking: Business model, efficiency and stability }\end{array}$ & 2013 & $\begin{array}{c}\text { Journal of Banking and } \\
\text { Finance }\end{array}$ & 394 \\
\hline Greene, W. Fixed and random effects in stochastic frontier models & 2005 & $\begin{array}{c}\text { Journal of Productivity } \\
\text { Analysis }\end{array}$ & 361 \\
\hline $\begin{array}{l}\text { Wang, Y.-S., Lin, H.-H., Luarn, P. Predicting consumer intention to use } \\
\text { mobile service }\end{array}$ & 2006 & $\begin{array}{c}\text { Information Systems } \\
\text { Journal }\end{array}$ & 328 \\
\hline $\begin{array}{l}\text { Kim, G., Shin, B., Lee, H.G. Understanding dynamics between initial } \\
\text { trust and usage intentions of mobile banking }\end{array}$ & 2009 & $\begin{array}{c}\text { Information Systems } \\
\text { Journal }\end{array}$ & 3278 \\
\hline
\end{tabular}

Source: Compiled by the author using data from Scopus

The same situation of publishing according to the WoS database -9 from 10 the most cited papers were published by the high ranked Journals (Table 2). In 2010 Nobel Peace Prize laureate Yunus Muhammad published the paper "Building Social Business Models: Lessons from the Grameen Experience" which cited 370 (Table 4), and it is the one most cited papers in the banking business model issues. The article traces the gradual development of Grameen's expertise in formulating social business models, which require new value propositions, value constellations and profit equations, and as such, resembles business model innovation. 
Table 4. The most cited papers on banking business model 1991-2019 according to WoS database

\begin{tabular}{|c|c|c|c|}
\hline Authors and Title & Year & Source title & Cited \\
\hline $\begin{array}{l}\text { Lecun, Y.; Bottou, L.; Bengio, Y.; et al. Gradient-based learning applied } \\
\text { to document recognition }\end{array}$ & 1998 & Proceedings of the IEEE & 9628 \\
\hline $\begin{array}{l}\text { Rust, R.T., Zahorik, A.J. Customer satisfaction, customer retention, and } \\
\text { market share }\end{array}$ & 1993 & Journal of Retailing & 731 \\
\hline $\begin{array}{l}\text { Stein, J.C. Information production and capital allocation: Decentralized } \\
\text { versus hierarchical firms }\end{array}$ & 2002 & Journal of Finance & 645 \\
\hline $\begin{array}{l}\text { TAM, K.Y.; KIANG, M.Y. Managerial applications of neural networks } \\
\text { - the case of bank failure predictions }\end{array}$ & 1992 & Management Science & 552 \\
\hline $\begin{array}{l}\text { Meuter, M.L.; Bitner, M.J.; Ostrom, A.L.; et al. Choosing among } \\
\text { alternative service delivery modes: An investigation of customer trial of } \\
\text { self-service technologies }\end{array}$ & 2005 & Journal of Marketing & 547 \\
\hline $\begin{array}{l}\text { Anderson, E.W., Fornell, C., Rust, R.T. Customer satisfaction, } \\
\text { productivity, and profitability: Differences between goods and services }\end{array}$ & 1997 & Marketing Science & 516 \\
\hline $\begin{array}{l}\text { Berger, A.N., Udell, G.F. Small business credit availability and } \\
\text { relationship lending: The importance of bank organisational structure }\end{array}$ & 2002 & Economic Journal & 403 \\
\hline $\begin{array}{l}\text { Yunus, M., Moingeon, } \quad \text { B., Lehmann-Ortega, } \quad \text { L. Building } \\
\text { Social Business Models: Lessons from the Grameen Experience }\end{array}$ & 2010 & Long Range Planning & 370 \\
\hline $\begin{array}{l}\text { Chirinko, R.S. Business fixed investment spending - modelling } \\
\text { strategies, empirical results, and policy implications }\end{array}$ & 1993 & $\begin{array}{l}\text { Journal of Economic } \\
\text { Literature }\end{array}$ & 360 \\
\hline $\begin{array}{l}\text { Beck, T., Demirgüç-Kunt, A., Merrouche, O. Islamic vs. conventional } \\
\text { banking: Business model, efficiency and stability }\end{array}$ & 2013 & $\begin{array}{l}\text { Journal of Banking and } \\
\text { Finance }\end{array}$ & 357 \\
\hline
\end{tabular}

Source: Compiled by the author using data from Scopus

The findings from VOSviewer identified 8 clusters of the papers which investigated the banking business model from the different points of views (Figure 5) (Appendix 1).

The first biggest cluster (red cluster) merged the paper which contained the keywords as follows: decision making, information management, risk management, risk assessment, sales, data mining etc. The second biggest cluster (green cluster) contained such issues as follows: financial crisis, bank, business model, regulation, z-score, efficiency, performance etc. The third biggest cluster (blue cluster) focused on banking, financial market, business cycle, lending behaviour, business model etc. The fourth-biggest cluster (the yellow one) merged the paper which contained the keywords as follows: sales, electronic commerce, competition, ebanking, internet banking, mobile banking etc. Next cluster (purple) located close to the first one (red) and yellow cluster (e-banking) contained such issues as follows: information system, business process, business process management, banking industry etc. They are connected threw the word "information system information management - process control - electronic commerce", "finance - design making - risk management - internet" etc. Next two small clusters orange (innovation and competition) and turquoise (commerce and sustainable development). The closer location of the abovementioned cluster to each other proved the stronger their relations. Such tendency allows making a conclusion, that information system, design making, new sales channels (e-banking, mobile banking etc.) and internal processes like planning, business process management becoming a relative part of banking business model. The findings proved that technology, fintech, information management, e-commerce become an important part of banking business models and is becoming increasingly popular in research and investigating by the huge range of the authors (Figure 6) (Appendix 2).

The smallest cluster (brown) focuses only on two keywords: cybernetic and the stock market. Noted, that three clusters brown, orange (innovation and competition) and turquoise (commerce and sustainable development) also located close to each other. This allows making a conclusion, that innovation and competition and sustainable development incoming in the attention of banks and their business models (Figure 7) (Appendix 3).

Thus, at the next stage, with the purpose to do a deep analysis of the co-citations on banking business model in second and third biggest clusters from Figure 5 were analysed in detail. The keywords were chosen as follows: financial crisis, bank, business model, regulation, z-score and banking, financial market, business cycle, lending behaviour, business model. The findings are shown in Figure 8 (Appendix 4). Thus, the findings proved the research hypothesis that the topic of banks and their role in financial in the papers which analysed the business model issues are very popular.

Considering the results, 8 clusters. The biggest was red, green, blue, yellow and purple. In this case, the red cluster contained keywords as follows: decision making, information management, risk management, risk assessment, sales, data mining. Thus, the findings proved the research hypothesis that the topic of banks and 
their role in financial in the papers which analysed the business model issues are very popular. At the same time, the most related areas with banking business model were sales, e-commerce, competition Islamic banking, performance, profitability and risk management.

\section{Conclusion}

The results of the analysis proved that the banking business model is a popular direction for investigation which formed in separate scientific school. Besides, the quantity of paper become increased from the 2012 year, that related to the active introduction of digital technologies in the banking business, and a corresponding change in the paradigm and types of business models of bank concerning fintech innovations, the emergence of cryptocurrencies, changes in the regulatory environment. The findings from VOSviewer allow allocating 8 clusters. Three among them have a close relationship. The first biggest cluster merged the keywords as follows: decision making, information management, risk management, risk assessment, sales, data mining etc. The second biggest cluster merged the keywords as follows: financial crisis, bank, business model, regulation, zscore, efficiency, performance etc. The third biggest cluster focused on banking, financial market, business cycle, lending behaviour, business model etc. The fourth-biggest cluster (the yellow one) merged the paper which contained the keywords as follows: sales, electronic commerce, competition, e-banking, internet banking, mobile banking etc. Such tendency allows concluding, that triangle "profitability - risk - soundness" and information technology, finteh, information management and regulation become the important part of the banking business model.

\section{References}

1. Accenture (2015). Banking Customer 2020. Rising Expectations Point to the Everyday Bank. [Online] Available at: https://www.accenture.com/t20150710T130243_w__us-en/_acnmedia/Accenture/ConversionAssets/DotCom/Documents/Global/PDF/Dualpub_17/Accenture-Banking-Consumer-Pulse.pdf.

2. Alani, E., Kamarudin, S., Alrubaiee, L. \& Tavakoli, R. (2019). A model of the relationship between strategic orientation and product innovation under the mediating effect of customer knowledge management. Journal of International Studies, 12(3), 232-242. doi:10.14254/2071-8330.2019/12-3/19.

3. Agarwal, Sumit, John C. Driscoll, Xavier Gabaix and David Laibson (2009). The age of reason: financial decisions over the life-cycle with implications for regulation. Brookings Papers on Economic Activity, 2, 51117. Available at: https://www.brookings.edu/wp-content/uploads/2016/07/2009b_bpea_agarwal.pdf.

4. Ayadi, R., Arbak, E., and de Groen, W.P. (2011). Business Models in European Banking: A pre and postcrisis screening, Centre for European Policy Studies (CEPS), Brussels. Available at: https://www.ceps.eu/ceps-publications/business-models-european-banking-pre-and-post-crisis-screening/.

5. Ayadi, R., Arbak, E., and de Groen, W.P. (2012). Regulation of European Banks and Business Models: Towards a new paradigm? Centre for European Policy Studies (CEPS), Brussels. Available at: https://www.ceps.eu/ceps-publications/regulation-european-banks-and-business-models-towards-newparadigm/.

6. Ayadi, R. and de Groen, W.P. (2014). Banking Business Models Monitor 2014: Europe, Montreal, Joint Centre for European Policy Studies (CEPS) and International Observatory on Financial Service Cooperatives (IOFSC) publication. Available at: https://www.ceps.eu/ceps-publications/banking-businessmodels-monitor-2014-europe/.

7. Ayadi, R. and de Groen, W.P. (2016). Banking Business Models Monitor 2015: Europe, Montreal, IRCCF. Available at: https://www.ceps.eu/ceps-publications/banking-business-models-monitor-2015-europe/.

8. Ayadi, R. (2019). Banking Business Models: Definition, Analytical Framework and Financial Stability Assessment. Springer. Available at: https://rymayadi.com/banking-business-models-definition-analyticalframework-and-financial-stability-assessment/.

9. Ayadi, R., Cucinelli, D., de Groen, W.P. (2019). Banking business models monitor 2019: EuropePerformance, Risk, Response to Regulation and Resolution: 2005-2017. Centre for European Policy Studies (CEPS), Brussels. Available at: https://www.ceps.eu/ceps-publications/banking-business-modelsmonitor-2019-europe/.

10.Bain \& Company (2015). Customer Behaviour, Experience and Loyalty in Retail Banking. [Online] Available at: http://www.bain.com/publications/articles/customer-loyalty-in-retail-banking-2015-global.aspx.

11.Beltratti, Andrea and Stulz, Rene M. (2009). Why Did Some Banks Perform Better during the Credit Crisis? A Cross-Country Study of the Impact of Governance and Regulation (July 13, 2009). Fisher College of Business Working Paper, No. 2009-03-012. Available at: https://papers.ssrn.com/sol3/papers.cfm?abstract_id=1433502.

12.Björk, S. (2015). Corporate customer loyalty within the banking Sector: The case of SEB. [Online] Available at: http://www.diva-portal.org/smash/get/diva2:886167/FULLTEXT01.pdf. 
13.DaSilva, C.M. and Trkman, P. (2014). Business Model: What It Is and What It Is Not. Long Range Planning, 47(6), 379-389. Available at:

https://mycourses.aalto.fi/pluginfile.php/415539/mod_folder/content/0/DaSilva_Trkman_2013.pdf?forced ownload $=1$.

14.Demirgüç-Kunt, A., Huizinga, H. (2010). Bank activity and funding strategies: the impact on risk and returns. Journal of Financial Economics 98, 626-650. Available at: https://papers.ssrn.com/sol3/papers.cfm?abstract_id=1350235.

15.Hryckiewicz, A., Kozlowski, L. (2015). Banking business models and the nature of financial crises. MPRA Paper 64072, University Library of Munich, Germany (2015). Available at: https://ideas.repec.org/p/pra/mprapa/64072.html, revised 09 Mar 2015.

16.Financial services (2015). The fintech revolution. A wave of startups is changing finance- for the better. [Online] Available at: http://www.economist.com/news/leaders/21650546-wave-startups-changingfinancefor-better-fintech-revolution.

17.Lautenschläger, S. (2017). Digital native? Fintechs and the future of banking. [Online] Available at: https://www.bankingsupervision.europa.eu/press/speeches/date/2017/ html/se170327_1.en.html.

18.Magretta, J. (2002). Why Business Models Matter. Harvard Business Review, 8. Available at: https://hbr.org/2002/05/why-business-models-matter.

19.Ogden, J. (2017). The Biggest Challenge Facing Banks in 2017 and a Checklist to Overcome It. [Online] Available at: https://www.mx.com/moneysummit/the-top-5-consumer-wants-in-banking-and-a-checklistto-meet-them.

20.Osterwalder, A. (2004). The Business Model Ontology - A Proposition in a Design Science Approach. $\mathrm{PhD}$ Thesis, University of Lausanne, Switzerland. Available at: http://www.hec.unil.ch/aosterwa/PhD/Osterwalder_PhD_BM_Ontology.pdf.

21.Wirtz, B.W., Pistoia, A., Ullrich, S. and Göttel, V. (2016). Business Models: Origin, Development and Future Research Perspectives. Long Range Planning, 49(1), 36-54. Available at: https://pdfs.semanticscholar.org/1bca/3bb962761b1165dfbf42ef658bf7c179bb8b.pdf.

22.Zott, C., Amit, R. and Massa, L. (2011). The Business Model: Recent Developments and Future Research. Journal of Management, 37(4), 1019-1042. Available at: http://www.cse.tkk.fi/fi/opinnot/T109.4300/2013/luennot-files/Zott\%20et\%20al.\%20-\%202011\%20-

\%20The\%20Business\%20Model\%20Recent\%20Developments\%20and\%20Future\%20Research.pdf. 


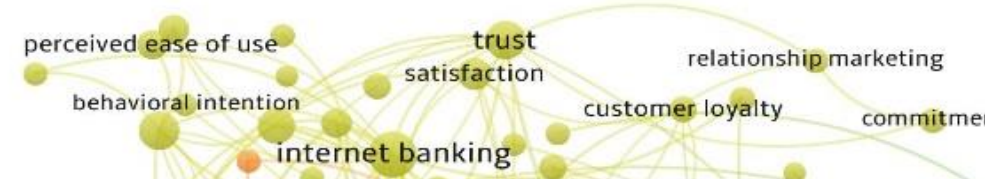

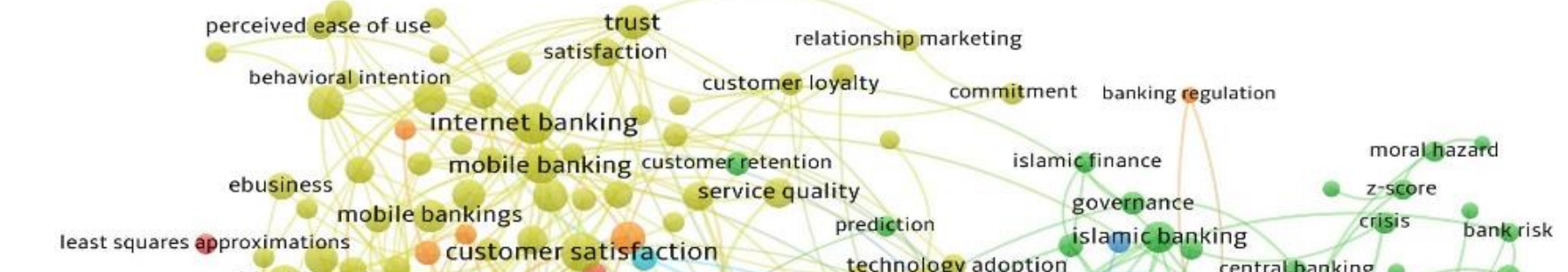

$\begin{array}{ccccc}\text { least squares approximations } & \text { customer satisfaction } & \text { prediction } & \text { goveblamic banking crisis bankrisk } \\ \text { world wide web alignment } & \text { technology adoption } & \text { centralbanking } & \end{array}$ vailability electronic commerce consumerbehavior bank business models secutity websites developing countries business model leadership panel data phishing outsourcing business performance performance leadership panel data financial crisis capital financial frictions

socjal networking (online) integration human profit banks regulation monetary policy

information systems competition banking sector savings competition(economics)

cryptography
security systems financial institution commerce finance article banking economicactivity network security big data financialinclusion business cycle competitive inteltigence value engineering risk management risks efficiency velationship banking macroeconornics

software engineering industry economics insurance business corporate strategy

network arc

business intelligence digital transformation sustainable development financial market income

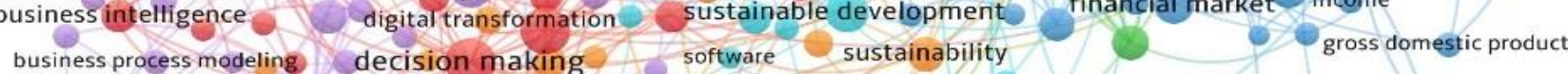

business process 10 economicgrowths simulation

business process management $\begin{gathered}\text { financial constraints } \\ \text { credit scoring benchmarking colimatechange }\end{gathered}$
balanced scorecard
emissions trading

\& Vosviewer

ahp

Figure 5. The network visualization of the co-citation of the papers on banking business model

Source: Compiled by the author using the Scopus and WoS database and VOSviewer tool 
Appendix 2

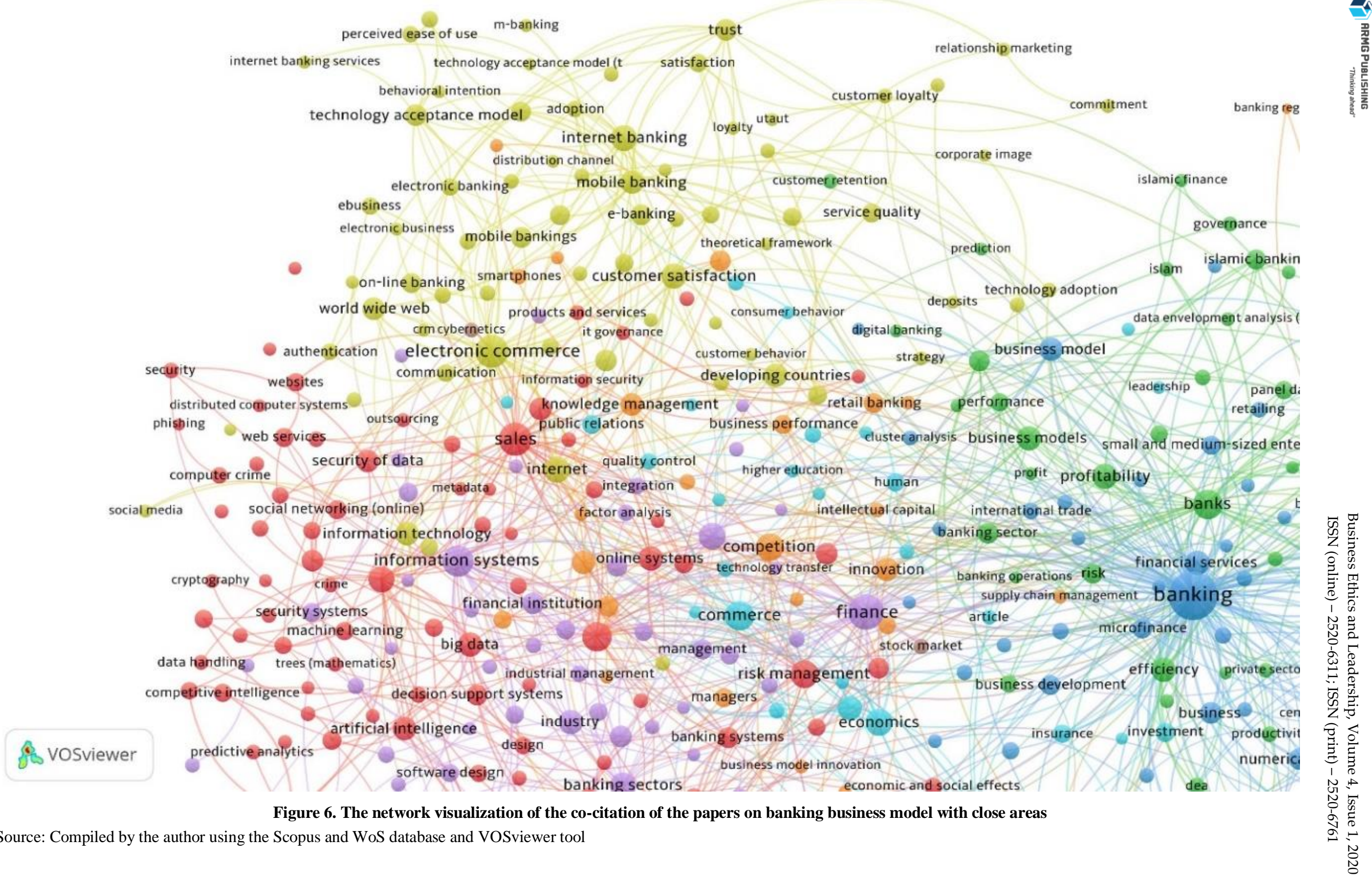


atp

\section{\& VOSviewer}

Figure 7. The network visualization of the co-citation of the papers on banking business model with close areas 
Appendix 4

ion

customer royarty

commitment

banking regulation

ərnet banking

unnel loyalty utaut

tobile banking

$$
10
$$

e-banking

$$
\text { customecretention }
$$$$
\text { theoretical framework }
$$

customer satisfaction

$$
\text { dservices deposits technology adoption }
$$

t governance consumer behavio

\section{digitalbanking}

corporate image

Customer behavior strategy

- data envelopment analysis (d

islam
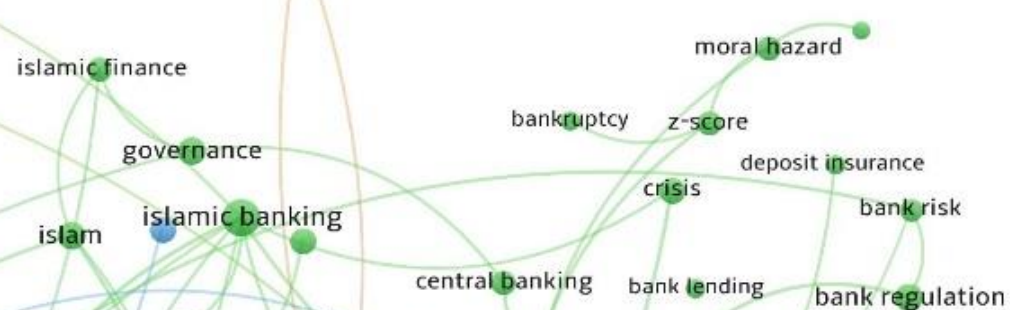

sme bank business models

security developing countries

edge management retail banking perform leadership panel data diversification bank capital

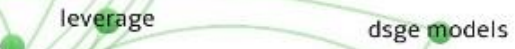

retailing financial intermediation

clusteranalysis business models small and medium-sized enterpr financial crisis

quality control higher education profit profitability

$\begin{array}{ccccc}\text { integration } & \text { higher ducation human } & \text { profit profitability } & \text { regulation islamism monetary policy capital regulation } \\ \text { actor analysis } & \text { intellectual capital } & \text { international trade } & \text { banks } & \text { bank pecformance }\end{array}$

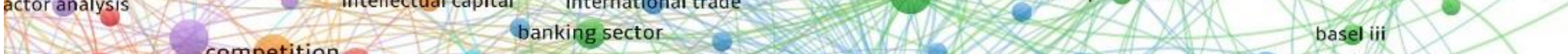

online systems technologytransfer innovation financial services 3 competition(economics)

innovation banking operations tisk financials

on commerce finance supplychain management banking tending behavior

C2 commerce finance article global banking business cycle interest rate management stock market 10 s.

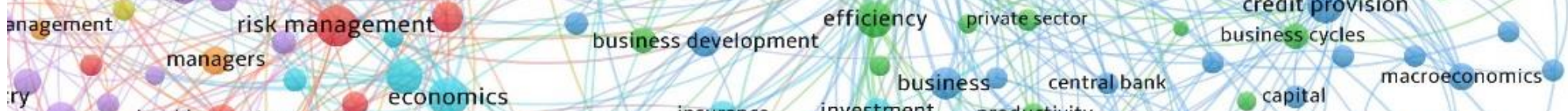

ry banking systems 0 economics

banking systems
business model innovation

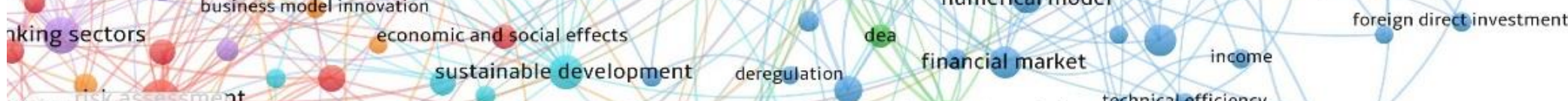

is \& $\begin{array}{lll}\text { ie } \\ \text { is }\end{array}$

Figure 8. The network visualization of the co-citation of the keywords on blue and green clusters

Sources: compiled by the author using the Scopus and WoS database and VOSviewer tool 